\title{
WANPRESTASI DALAM PERJANJIAN JUAL BELI MOBIL MICROBUS (STUDI KASUS PUTUSAN NOMOR 40/PDT.G/2012/PN. MDN.) HENDRI DWITANTO
}

\author{
Program Studi Magister Kenotariatan \\ Fakultas Hukum Universitas Sumatera Utara \\ Jalan Dr. T. Mansur Nomor 9, Kampus Padang Bulan, Medan \\ Telp.(061)8211633, Email: hendri.dwitanto@gmail.com
}

\begin{abstract}
A sale and purchase is a mutual agreement in which one party is committed themselves to transfer ownership rights over something, whereas another party promises to pay some amount of money in return for acquiring the ownership rights. There is a dispute over a sale and purchase in the Ruling Number 40/Pdt.G/2012/PN.Mdn. which is interesting to study i.e. how a verbal agreement is fulfilled so that it binds both parties, what legal consequences are there if one party defaults on a verbal sale and purchase agreement, and how the Judges' legal consideration is concerning the dispute over a default on the sale and purchase agreement of microbus in accordance with Ruling Number 40/Pdt.G/2012/PN.Mdn. pursuant to the prevailing laws. This is a descriptive juridical normative research. It uses secondary data. It applies descriptive analysis and is concluded using deductive reasoning method. A verbal agreement is legally binding when all parties involved meet and agree to sell and purchase. A sale and purchase is considered to have taken place when all parties involved have agreed about something and its price, although the item is not handed and paid yet. The legal consequence for a default on a sale and purchase agreement is that it causes rights for one of the parties who is injured, to file a claim over four things, namely: fulfilment of agreement, fulfilment of agreement with compensation, cancellation of agreement, and cancellation of agreement with compensation. The Judges' legal consideration on the dispute over the sale and purchase agreement of microbus in Ruling Number 40/Pdt.G/2012/PN.Mdn., is that the agreement has substantially been in line with prevailing laws; nevertheless, the judges still fail to notice some things.
\end{abstract}

Keywords: Verbal Agreement; Sale and Purchase; Default

\section{Intisari}

Jual beli ialah suatu perjanjian bertimbal balik dalam mana pihak yang satu berjanji untuk menyerahkan hak milik atas suatu barang, sedangkan pihak yang lainnya berjanji untuk membayar harga yang terdiri atas sejumlah uang sebagai imbalan dari perolehan hak milik tersebut. Terdapat satu sengketa jual beli menurut Putusan Nomor 40/Pdt.G/2012/PN. Mdn. yang cukup menarik untuk dikaji berkaitan dengan bagaimana menentukan waktu tercapainya kesepakatan sehingga berlaku mengikat bagi kedua belah pihak dalam bentuk perjanjian tidak tertulis, bagaimana akibat hukum yang timbul apabila salah satu pihak melakukan wanprestasi dalam perjanjian jual beli yang tidak tertulis, dan bagaimana pertimbangan hukum Hakim dalam sengketa tentang wanprestasi atas perjanjian jual beli mobil microbus menurut Putusan Nomor 40/Pdt.G/2012/PN. Mdn. telah sesuai dengan hukum yang berlaku. Jenis penelitian yang digunakan adalah jenis penelitian yuridis normatif. Sifat penelitian ini ialah deskriptif. Sumber data yang digunakan adalah data sekunder. Sifat penelitian ini adalah penelitian deskriptif analitis dan penarikan kesimpulan menggunakan metode deduktif. Mengikatnya suatu kesepakatan dalam perjanjian jual beli yang tidak tertulis itu saat para 
pihak yang bertemu itu sepakat untuk melakukan jual beli. Jual beli dianggap telah terjadi antara penjual dan pembeli, pada saat orang-orang itu mencapai kesepakatan tentang suatu barang beserta harganya, meskipun barang itu belum diserahkan dan harganya belum dibayar. Akibat hukum yang timbul apabila para pihak melakukan wanprestasi dalam perjanjian jual beli yaitu muncul suatu hak bagi salah satu pihak yang dirugikan tersebut untuk menuntut empat hal yaitu sebagai berikut: pemenuhan perjanjian, pemenuhan perjanjian disertai ganti kerugian, pembatalan perjanjian, pembatalan perjanjian disertai ganti kerugian. Pertimbangan hukum majelis hakim dalam sengketa perjanjian jual beli mobil microbus pada putusan nomor 40/Pdt.G/2012/PN. Mdn. secara keseluruhan sudah sesuai dengan aturan hukum yang berlaku, namun juga terdapat beberapa hal yang masih luput dari perhatian hakim.

\section{A. Latar Belakang}

KUHPerdata mengenal berbagai perjanjian. Contoh dari perjanjian yang sering ditemui dalam kegiatan sehari-hari antara lain seperti: jual beli; sewamenyewa; tukar-menukar; pinjammeminjam; dan lain-lain. Jual Beli adalah suatu perjanjian bertimbal balik dalam mana pihak yang satu (penjual) berjanji untuk menyerahkan hak milik atas suatu barang, sedangkan pihak yang lainnya (pembeli) berjanji untuk membayar harga yang terdiri atas sejumlah uang sebagai imbalan dari perolehan hak milik tersebut. ${ }^{1}$

Sifat konsensual dari jual beli tersebut ditegaskan dalam Pasal 1458 KUHPerdata yang berbunyi: "Jual beli dianggap telah tejadi antara kedua belah pihak, segera setelah orang-orang itu mencapai kesepakatan tentang barang tersebut beserta harganya, meskipun barang itu belum diserahkan dan harganya belum dibayar." Aturan itu mengatur tentang suatu perjanjian jual beli yang

\footnotetext{
${ }^{1}$ Subekti, Aneka Perjanjian, Citra Aditya Bakti, Bandung, 1995, h. 1.
}

dianggap telah terjadi antara penjual dan pembeli ketika kedua belah pihak mencapai kesepakatan tentang harga dan barang, meskipun barang yang menjadi objek perjanjian jual beli tersebut belum diserahkan maupun harganya belum dibayar. Apabila salah satu pihak yang telah sepakat di awal tersebut mengingkari perjanjian itu, maka dapat dikatakan pihak tersebut wanprestasi.

Wanprestasi adalah suatu kondisi di mana penjual atau pembeli berada dalam keadaan tidak dapat menjalankan atau memenuhi suatu prestasi yang telah diperjanjikan. ${ }^{2}$ Secara sederhana, penjual diwajibkan menyerahkan barang sesuai dengan apa yang telah disepakati di awal, dan pembeli wajib membayar sejumlah uang yang juga telah disepakati sebelumnya. Apabila apa yang telah disepakati oleh penjual dan pembeli dari awal perjanjian tersebut tidak dijalankan sebagaimana mestinya, maka para pihak

\footnotetext{
${ }^{2}$ Rudy Haposan Siahaan, Hukum Perikatan Indonesia, Intelegensia Media, Malang, 2017, h. 97.
} 
atau salah satu pihak dapat dinyatakan wanprestasi. $^{3}$

Pada dasarnya suatu perjanjian akan berlangsung dengan baik jika para pihak yang melakukan perjanjian tersebut dilandasi oleh itikad baik (good faith), namun apabila salah satu pihak tidak beritikad baik atau tidak melaksanakan kewajibannya maka timbullah perbuatan wanprestasi. ${ }^{4}$ Seperti halnya yang terjadi dalam kasus perjanjian jual beli yang telah diputus oleh Pengadilan Negeri Medan, Putusan Nomor 40/Pdt.G/2012/PN.Mdn.

Awalnya antara pembeli (CV Berlian Trans) dengan penjual (PT Isuindomas Putra) telah dilakukan perjanjian secara lisan (tidak tertulis) untuk melakukan jual beli 12 (dua belas) unit mobil microbus. Satu unit bus yang dijual oleh penjual seharga $\mathrm{Rp}$ 242.000.000 (dua ratus empat puluh dua juta rupiah). Jika dikalikan dua belas, maka total harga bus yaitu $\mathrm{Rp}$ 2.904.000.000 (dua miliar sembilan ratus empat juta rupiah). Untuk pembelian mobil tersebut diperjanjikan bahwa akan dilakukan secara kredit dengan mengajukannya kepada pihak ketiga yaitu perusahaan leasing. Kemudian untuk

\footnotetext{
${ }^{3}$ Riry Elizabeth Hutabarat, Wanprestasi dalam Perjanjian Jual Beli Tenaga Listrik, Jurnal Lex Jurnalica, April 2015, h. 36.

${ }^{4}$ Munir Fuady, Hukum Kontrak (Dari Sudut Pandang Hukum Bisnis), Citra Aditya Bakti, Bandung, 2001, h. 89.
}

perjanjian kredit disepakati pembayaran uang muka sebesar 30\% (tiga puluh persen) dari total harga microbus yaitu Rp 871.200.000 (delapan ratus tujuh puluh satu juta dua ratus ribu rupiah). Pembeli dalam hal ini telah membayar tanda jadi kepada penjual sebesar Rp 60.000.000 (enam puluh juta rupiah). Setelah dibayar tanda jadi tersebut berarti sisa uang muka yang harus dibayarkan oleh pembeli yaitu Rp 811.200.000 (delapan ratus sebelas juta dua ratus ribu rupiah)

Disepakati bahwa dengan tanda jadi tersebut, penjual akan menyerahkan 12 (dua belas) unit bus kepada pembeli pada saat yang telah ditentukan kedua belah pihak disertai dengan pelunasan seluruh sisa uang muka yang belum dibayar oleh pembeli. Namun di waktu untuk menyerahkan dua belas unit microbus tersebut sampai, pihak penjual tidak menyerahkan bus tersebut kepada pembeli dengan alasan pengajuan kredit oleh penjual kepada perusahaan leasing ditolak. Setelah itu, dilakukanlah pertemuan untuk membahas keterlambatan penyerahan microbus. Mengenai pengunduran waktu penyerahan microbus tidak menemukan titik temu. Untuk mendapatkan persetujuan kredit dari perusahaan leasing diperlukan waktu yang tidak sesuai dengan permintaan dari pembeli sehingga pembeli tidak sepakat 
dengan waktu yang diminta oleh penjual. Atas dasar ini pembeli menggugat penjual yang telah melakukan tindakan wanprestasi atas perjanjian awal di antara mereka untuk melakukan jual beli dua belas unit microbus.

Kasus yang telah diputus oleh Pengadilan Negeri Medan ini menyatakan adanya tindakan wanprestasi dari kedua belah pihak. Baik dari pembeli maupun penjual. Penjual diharuskan mengembalikan uang tanda jadi yang telah dibayar oleh pembeli sebesar Rp 60.000.000 (enam puluh juta rupiah), sedangkan pembeli diharuskan membayar kerugian materiil yang dialami oleh penjual sebesar Rp 49.400.000 (empat puluh sembilan juta empat ratus ribu rupiah). Jumlah uang sebesar Rp 49.400.000 (empat puluh sembilan juta empat ratus ribu rupiah) ini diputuskan hakim berdasarkan gugatan balik dari PT Isuindomas Putra selaku penjual karena telah mengeluarkan biaya untuk melakukan pemasangan karoseri (penutup kerangka mobil), pengecatan dari warna silver (perak) ke putih sebanyak 12 unit, pengecatan logo Berlian Trans sebanyak dua unit, pengurusan faktur kendaraan bermotor, dan penyimpanan dari tanggal 8 Desember 2011 sampai dengan 26 Januari 2012. Total kerugian materiil yang digugat balik oleh PT Isuindomas Putra adalah sebesar Rp 916.151.000 (sembilan ratus enam belas juta seratus lima puluh satu ribu rupiah), namun yang dikabulkan oleh hakim hanya sebesar Rp 49.400.000 (empat puluh sembilan juta empat ratus ribu rupiah).

\section{B. Rumusan Masalah}

Berdasarkan pada uraian latar belakang penelitian tersebut, adapun yang menjadi perumusan permasalahan dalam penelitian ini adalah sebagai berikut:

1. Bagaimana menentukan waktu tercapainya kesepakatan sehingga berlaku mengikat bagi kedua belah pihak dalam bentuk perjanjian tidak tertulis?

2. Bagaimana akibat hukum yang timbul apabila salah satu pihak melakukan wanprestasi dalam perjanjian jual beli yang tidak tertulis?

3. Bagaimana pertimbangan hukum Hakim dalam sengketa tentang wanprestasi atas perjanjian jual beli mobil microbus menurut Putusan Nomor 40/Pdt.G/2012/PN. Mdn. telah sesuai dengan hukum yang berlaku?

\section{Metode Penelitian}

Berdasarkan perumusan masalah dalam menyusun penelitian ini, jenis penelitian yang digunakan adalah jenis penelitian yuridis normatif. Sifat penelitian ini ialah deskriptif. Sumber bahan hukum yang 
digunakan adalah data sekunder dengan bahan hukum primer, bahan hukum sekunder dan bahan hukum tersier. Sifat penelitian ini adalah penelitian deskriptif analitis dan penarikan kesimpulan menggunakan metode deduktif.

\section{Pembahasan}

\section{Waktu Mengikatnya Suatu}

\section{Kesepakatan dalam Bentuk}

\section{Perjanjian Tidak Tertulis}

Pada Suatu perjanjian jual beli memiliki subjek hukum yaitu pembeli dan penjual. Subjek hukum ini bertindak sebagai para pihak dalam perjanjian jual beli ini. Para pihak yang melakukan perjanjian jual beli memiliki hak dan kewajiban masing-masing. Apabila hak dan kewajiban yang telah mereka sepakati tersebut dilanggar oleh pihak lain, maka dapat terjadi yang namanya wanprestasi. Wanprestasi dapat menimbulkan kerugian bagi salah satu pihak dalam perjanjian. Wanprestasi itu mengusik kepentingan salah satu pihak dalam perjanjian dan oleh karena itu, undang-undang (KUHPerdata) menjamin perlindungan hukum bagi para pihak dalam perjanjian. $^{5}$

Perjanjian dilakukan oleh penjual dan pembeli bisa dalam bentuk tertulis

${ }^{5}$ Akbar Ramadhan, dkk., Kekuatan Hukum Garansi Secara Lisan dalam Perjanjian Jual Beli Komputer Rakitan, Pactum Law Journal, Volume 1, Nomor 04, 2018, h. 341. maupun tidak tertulis. Apabila tertulis, maka dapat lebih memudahkan pembuktian jika terjadi suatu permasalahan di kemudian hari. Walaupun tidak melakukan perjanjian secara tertulis, perjanjian tersebut tetap sah asalkan telah disepakati oleh kedua belah pihak. ${ }^{6}$

Jual beli ialah suatu kesepakatan antara pihak yang satu mengikatkan dirinya untuk menyerahkan suatu barang, dan pihak yang lain untuk membayar harga yang telah dijanjikan. Pihak yang menyerahkan barang disebut penjual, dan pihak yang membayar harga disebut pembeli. $^{7}$

\section{Sebagaimana} diketahui, KUHPerdata menganut sistem bahwa perjanjian jual beli itu hanya obligatoir saja, artinya bahwa perjanjian jual beli baru meletakkan hak dan kewajiban bertimbal-balik antara kedua belah pihak (penjual dan pembeli) yaitu meletakkan kepada si penjual kewajiban untuk menyerahkan hak milik atas barang yang dijualnya, sekaligus memberikan kepadanya hak untuk menuntut pembayaran harga yang telah disetujui dan di sebelah lain meletakkan kewajiban

${ }^{6}$ Tahi Bona Sinambela, Kekuatan Hukum Perjanjian Pinjam-Meminjam Uang di Bawah Tangan (Putusan Mahkamah Agung Nomor 967 $K / P d t / 2016)$, Tesis, Universitas Sumatera Utara, Medan, 2017, h. 63.

${ }^{7}$ Gunawan Widjaja dan Kartini Muljadi, Seri Hukum Perikatan Jual Beli, PT Rajagrafindo Persada, Jakarta, 2003, h. 12. 
kepada si pembeli untuk membayar harga barang sebagai imbalan haknya untuk menuntut penyerahan hak milik atas barang yang dibelinya. ${ }^{8}$

Dengan perkataan lain, perjanjian jual beli menurut KUHPerdata itu belum memindahkan hak milik. Adapun hak milik baru berpindah dengan dilakukannya levering atau penyerahan. Sistem dalam KUHPerdata tersebut levering merupakan suatu perbuatan yuridis guna memindahkan hak milik (transfer of ownership) yang caranya ada tiga macam, tergantung dari macamnya barang. ${ }^{9}$

Mengenai barang tertentu ditetapkan oleh Pasal 1460 KUHPerdata bahwa barang itu sejak saat pembelian (saat ditutupnya perjanjian) adalah atas tanggungan si pembeli, meskipun penyerahannya belum dilakukan dan si penjual berhak menuntut harganya.

Mengenai barang seperti itu Pasal 1460 KUHPerdata tersebut di atas menetapkan bahwa risiko dipikulkan kepada si pembeli, biarpun barangnya belum diserahkan. Jadi, umpamanya lemari tersebut di atas dalam perjalanan sewaktu sedang diangkut ke rumahnya si pembeli di mana ia akan diserahkan, hancur karena suatu kecelakaan, maka tetaplah si pembeli diharuskan membayar

${ }^{8}$ Subekti, Aneka Perjanjian, Citra Aditya Bakti, Bandung, 1995, h. 78.

${ }^{9}$ Ibid., h. 82. harganya. Inilah yang dinamakan memikul risiko atas suatu barang. ${ }^{10}$

Banyak orang akan bertanya, apakah itu adil? Secara terus terang harus kita jawab memang itu tidak adil. Sebab, bukankah si pembeli lemari itu (di dalam sistem KUHPerdata) belum pemilik. Ia baru seorang calon pemilik dan baru menjadi pemilik pada saat barang itu diserahkan kepadanya (di rumahnya). Kemudian selama barang belum diserahkan kepada pembeli, apabila si penjual jatuh pailit, barang itu masih termasuk dalam harta kekayaan (boedel) si penjual. $^{11}$

Sebagaimana diketahui, Mahkamah Agung dengan surat edarannya Nomor 3 Tahun 1963 telah menyatakan beberapa pasal dari KUHPerdata tidak berlaku lagi, antara lain Pasal 1460 KUHPerdata. Dalam anggapan kami Surat Edaran Mahkamah Agung itu merupakan suatu anjuran kepada semua hakim dan pengadilan untuk membuat yurisprudensi yang menyatakan Pasal 1460 KUHPerdata tersebut sebagai pasal yang mati dan karena itu tidak boleh dipakai lagi.

Dapat dibayangkan bahwa dalam perjanjian, antara penawaran dan akseptasi, selalu ada selang suatu jangka waktu tertentu yang bisa singkat saja,

\footnotetext{
${ }^{10}$ Ibid., h. 25.

${ }^{11}$ Ibid., h. 26.
} 
tetapi bisa memakan waktu yang cukup lama. Pada prinsipnya penawaran menjadi batal, kalau ditolak pihak lain dan sebelum diterima oleh pihak lain, penawaran tersebut dapat ditarik kembali. ${ }^{12}$

Pendapat yang demikian dapat menimbulkan masalah, yaitu dalam hal sesudah ada penerimaan, tetapi sebelum jawaban tersebut sampai kepada pihak yang menawarkan, orang yang menawarkan itu menyatakan penarikan kembali penawarannya. Apakah sudah terjadi kesepakatan antara kedua pihak tersebut? Ini semua bergantung dari jawaban, kapan dapat dianggap telah terjadi atau lahir perjanjian. ${ }^{13}$

Masalah tersebut di atas berkaitan dengan masalah penetapan kapan dianggap bahwa pihak lain telah memberikan akseptasinya, yang kesulitan adalah, karena para pihak tidak berada/tinggal di kota yang sama dan hubungannya dilakukan melalui alat komunikasi seperti surat yang membutuhkan waktu yang lama dalam melakukan pengiriman. Namun, dengan semakin berkembangnya zaman, komunikasi sekarang ini sudah semakin memudahkan para pihak yang memiliki

\footnotetext{
${ }^{12}$ Indah Purnama Sari Nasution, Analisis Yuridis atas Putusan Mahkamah Agung Nomor 32 PK/Pdt/2012 tentang Perjanjian Simulasi Jual Beli Tanah, Tesis, Universitas Sumatera Utara, Medan, 2018, h. 101.

${ }^{13}$ J. Satrio, Hukum Perikatan (Perikatan yang Lahir dari Perjanjian) Buku I, PT Citra Aditya Bakti, Bandung, 1995, h. 255.
}

kedudukan yang jauh. Mereka dapat memberikan persetujuan atas suatu penawaran melalui alat komunikasi seperti telepon genggam, maupun dengan komunikasi online melalui telepon pintar (smart phone). Walaupun mengunakan surat menyurat elektronik (email), suatu jawaban dapat langsung diterima oleh pihak lain saat itu juga. ${ }^{14}$

Melalui itu secara tidak langsung kita mengakui bahwa kalau perjanjian itu ditutup secara lisan antara orang-orang yang saling berhadapan, tidak akan ada masalah kapan perjanjian lahir, karena pada saat orang menerima penawaran yang ditujukan kepadanya, orang yang memberikan penawaran langsung tahu jawabannya (persetujuannya). Lain halnya kalau kedua belah pihak berada di dua tempat yang berlainan. Dengan perkataan lain, di sini adalah penting unsur "membuat pernyataannya diketahui oleh pihak lain". ${ }^{15}$

Perjanjian yang didasarkan pada perjanjian tidak tertulis, akan lebih mudah untuk diketahui kapan suatu perjanjian itu

\footnotetext{
${ }^{14}$ Dewi Fitri, Analisis Perbuatan Wanprestasi Pihak Penyewa dalam Perjanjian Sewa-Menyewa Rumah (Studi Kasus Putusan Mahkamah Agung RI Nomor 1507 K/Pdt/2010), Tesis, Universitas Sumatera Utara, Medan, 2013, h. 92.

${ }^{15}$ Fauzi Sumardi dan Ridho Mubarak, Tinjauan Yuridis terhadap Perjanjian Kerja yang Dibuat Secara Lisan, Jurnal Ilmiah Penegakan Hukum, Volume 5, Nomor 2, Desember 2018, h. 11.
} 
mengikat bagi kedua belah pihak. Jual beli dianggap telah terjadi antara penjual dan pembeli, pada saat orang-orang itu mencapai kesepakatan tentang suatu barang beserta harganya, meskipun barang itu belum diserahkan dan harganya belum dibayar. Hal ini memperlihatkan apabila antara para pihak sudah menyetujui perjanjian mengenai suatu harga dan barang tertentu, maka di antara mereka telah terikat oleh perjanjian jual beli itu dan tidak boleh mengganggap perjanjian itu belum terjadi karena barang yang belum diserahkan. Sehingga apabila seseorang menyangkal bahwa belum terjadi perjanjian jual beli karena barang belum diserahkan, maka ia dapat dikatakan telah ingkar janji (wanprestasi). Hal ini diatur dalam Pasal 1458 KUHPerdata yang berisi, "Jual beli dianggap telah terjadi antara kedua belah pihak, segera setelah orang-orang itu mencapai kesepakatan tentang barang tersebut beserta harganya, meskipun barang itu belum diserahkan dan harganya belum dibayar. ${ }^{16}$

2. Akibat Hukum yang Timbul Apabila Para Pihak Melakukan Wanprestasi dalam Perjanjian Jual Beli

Pada Perjanjian jual beli barang dalam aktivitas masyarakat saat ini telah

${ }^{16}$ Setiawan, Aneka Masalah Hukum dan Hukum Acara Perdata, Alumni, Bandung, 1992, h. 77. banyak ditemui, terutama untuk memenuhi kebutuhan masyarakat atau dunia bisnis dalam pelaksanaan perdagangan atau transaksi bisnis dengan harapan para pelaksananya dapat memperoleh laba/keuntungan-keuntungan dari transaksi yang dilakukan. Di dalam pelaksanaan transaksi yang dilakukan sebagai pelaksanaan dari perjanjian jual beli, dalam praktiknya sangat beragam seperti pelaksanaan dari perjanjian jual beli dilaksanakan dengan baik oleh para pihak, sehingga para pihak dapat mengambil keuntungan dari perjajian yang telah dilakukan. Akan tetapi banyak juga pihakpihak yang tidak bertanggung jawab dengan berbagai macam motif yang digunakan dalam membuat perjanjian jual beli, dengan berbagai macam alasan/dalih yang diampaikan sehingga perjanjian jual beli yang telah disepakati tersebut tidak dilaksanakan/ditepati. ${ }^{17}$

Secara yuridis, setiap perjanjian yang dibuat secara sah akan mengikat sebagai undang-undang bagi mereka yang telah membuatnya. Dengan demikian maka pihak-pihak yang mengadakan perjanjian itu satu sama lain terikat dengan janji yang mereka buat. Biasanya suatu perjanjian adalah timbal balik, kecuali

\footnotetext{
${ }^{17}$ Aan Handriani, Keabsahan Perjanjian Jual Beli Secara Tidak Tertulis Berdasarkan Hukum Perdata, Rechtsregel Jurnal Ilmu Hukum, Volume 1, Nomor 2, Desember 2018, h. 293.
} 
dalam perjanjian yang bersifat sepihak (eenzijdig overeenkomst). ${ }^{18}$

Perjanjian, baik yang sepihak maupun yang dua pihak adalah suatu perbuatan hukum, yang tiap-tiap perbuatan yang menimbulkan akibat hukum, baik berupa timbulnya hak maupun berupa lenyapnya hak. Perbuatan hukum yang bersegi satu hanya memerlukan kehendak atau pernyataan kehendak dari satu pihak saja sudah cukup menimbulkan akibat hukum. Demi terwujudnya suatu perbuatan hukum yang bersegi dua, maka diperlukan adanya pernyataan kehendak antara dua pihak atau lebih misalnya, dalam hal jual beli sesuatu benda, hanya terjadi sesudah adanya pernyataan kehendak antara penjual dan pembeli mengenai barang dan harga dalam suatu transaksi jual beli. ${ }^{19}$

Antara kedua pihak, baik penjual maupun pembeli ditimbulkan hak dan kewajiban secara timbal balik. Si pembeli berkewajiban membayar harga barang yang disepakati dan berhak menerima barang yang telah dibayar, sebaliknya si penjual berkewajiban menyerahkan barang yang telah dijual dan berhak menerima uang pembayaran dari transaksi yang dilakukan. Dengan demikian, hak bagi satu

\footnotetext{
${ }^{18}$ Karya Ilmiah Dosen-Dosen Jurusan Perdata, Pelangi Perdata, Medan: Fakultas Hukum Universitas Sumatera Utara. 1980, h. 75.

${ }^{19}$ Agus Yudha Hernoko, Hukum Perjanjian Asas Proporsionalitas dalam Kontrak Komersial, Kencana, Jakarta, 2010, h. 47.
}

pihak merupakan kewajiban bagi pihak lainnya, sedang kewajiban bagi pihak yang satu menjadi hak bagi pihak yang lain. ${ }^{20}$

Suatu perjanjian jual beli yang tidak dilaksanakan (wanprestasi), maka dapat menimbulkan akibat hukum. Akibatakibat hukum tersebut diatur dalam Pasal 1243 sampai dengan Pasal 1352, Pasal 1266 dan Pasal 1267 KUHPerdata. Berikut ini ialah penjelasan mengenai pasal-pasal tersebut di atas.

Pasal 1243 KUHPerdata berbunyi sebagai berikut:

"Penggantian biaya, kerugian dan bunga karena tak dipenuhinya suatu perikatan mulai diwajibkan, bila debitur, walaupun telah dinyatakan lalai, tetap lalai untuk memenuhi perikatan itu, atau jika sesuatu yang harus diberikan atau dilakukannya hanya dapat diberikan atau dilakukannya dalam waktu yang melampaui waktu yang telah ditentukan"

Pasal ini bermaksud untuk menjelaskan mengapa seseorang dapat dibebani pembayaran ganti kerugian. Penentuan mulainya penghitungan pembayaran ganti kerugian itu tegantung dari ada tidaknya jangka waktu yang

\footnotetext{
${ }^{20}$ Marvita Langi, Akibat Hukum Terjadinya Wanprestasi dalam Perjanjian Jual Beli, Lex Privatum, Volume 4, Nomor 3, Maret 2016, h. 101.
} 
dijadikan patokan untuk kelalaian salah satu pihak dalam perjanjian jual beli. ${ }^{21}$

Selain wanprestasi itu disebabkan oleh keadaan yang tak terduga atau di luar kemampuan salah satu pihak, untuk dibebaskan dari ganti kerugian akibat wanprestasi, salah satu pihak itu pun tidak harus tidak dalam keadaan beriktikad buruk. Karena kalau salah satu pihak tersebut beriktikad buruk, dia tetap dibebani untuk membayar ganti kerugian. $^{22}$

Pasal 1245 KUHPerdata berbunyi sebagai berikut: "Tidak ada penggantian biaya. kerugian dan bunga. bila karena keadaan memaksa atau karena hal yang terjadi secara kebetulan, debitur terhalang untuk memberikan atau berbuat sesuatu yang diwajibkan, atau melakukan suatu perbuatan yang terlarang baginya."

Pasal ini pada dasarnya sama dengan pasal sebelumnya, yaitu menerangkan tentang pembebasan salah satu pihak dalam membayar ganti kerugian jika wanprestasi karena adanya suatu

${ }^{21}$ Ahmad Miru dan Pati Saka, Hukum Perikatan Penjelasan Makna Pasal 1233 Sampai 1456 KUHPerdata, PT Rajagrafindo Persada, Jakarta, 2008, h. 66.

${ }^{22}$ Raminalai Dakhi, Pelaksanaan Asas Penyewa Sebagai Tuan Rumah yang Baik dalam Suatu Perjanjian Sewa-Menyewa Rumah, Tesis, Universitas Sumatera Utara, Medan, 2017, h. 82. keadaan yang memaksa atau tidak disengaja. $^{23}$

Pada dasarnya Pasal 1246 KUHPerdata ini hanya menguraikan kembali tentang komponen kerugian yang berupa biaya, rugi, dan bunga, di mana biaya dan rugi digolongkan sebagai kerugian nyata, sedangkan bunga digolongkan sebagai kehilangan keuntungan yang diharapkan.

Walaupun demikian, sebenarnya selain bunga, masih ada kehilangan keuntungan yang diharapkan, yaitu keuntungan yang mungkin diperoleh dalam perdagangan. Hanya untuk memberikan perlindungan kepada salah satu yang dirugikan, kehilangan keuntungan yang diharapkan ini harus dibatasi hanya meliputi keuntungan yang benar-benar di depan mata yang nyatanyata dapat diperoleh seandainya pihak tersebut tidak wanprestasi. ${ }^{24}$

Pasal 1247 KUHPerdata berbunyi sebagai berikut: "Debitur hanya diwajibkan mengganti biaya, kerugian dan bunga, yang diharap atau sedianya dapat diduga pada waktu perikatan diadakan,

${ }^{23}$ Ahmad Miru dan Pati Saka, Hukum Perikatan Penjelasan Makna Pasal 1233 Sampai 1456 KUHPerdata, PT Rajagrafindo Persada, Jakarta, 2008, h. 67.

${ }^{24}$ Hendry, Analisis Hukum atas Transaksi yang Menggunakan Media Elektronik Untuk Jual Beli Apartemen dan Villa (Studi Putusan Nomor 169/Pdt.G/2015/PN.Dps), Tesis, Universitas Sumatera Utara, Medan, 2018, h. 108. 
kecuali jika tidak dipenuhinya perikatan itu disebabkan oleh tipu daya yang dilakukannya."

Pasal ini sebagai penegasan tentang pembatasan ganti kerugian yang dapat dituntut dari salah satu pihak dalam suatu perjanjian, yaitu kerugian yang nyatanyata telah dapat diperhitungkan pada saat perjanjian tersebut dibuat oleh para pihak. Seperti halnya iktikad buruk, tipu daya yang dilakukan oleh salah satu pihak dapat pula menjadi penghalang untuk membebaskan pihak yang lain dari pembayaran ganti kerugian. ${ }^{25}$

Pasal 1248 KUHPerdata berbunyi sebagai berikut:

"Bahkan jika tidak dipenuhinya perikatan itu disebabkan oleh tipu daya debitur, maka penggantian biaya, kerugian dan bunga, yang menyebabkan kreditur menderita kerugian dan kehilangan keuntungan, hanya mencakup hal-hal yang menjadi akibat langsung dari tidak dilaksanakannya perikatan itu."

Pasal 1249 KUHPerdata berbunyi sebagai berikut: "Jika dalam suatu perikatan ditentukan bahwa pihak yang lalai memenuhinya harus membayar suatu jumlah uang tertentu sebagai ganti

${ }^{25}$ Ahmad Miru dan Pati Saka, Hukum Perikatan Penjelasan Makna Pasal 1233 Sampai 1456 KUHPerdata, PT Rajagrafindo Persada, Jakarta, 2008, h. 69. kerugian, maka kepada pihak lain-lain tak boleh diberikan suatu jumlah yang lebih ataupun yang kurang dari jumlah itu."

Pasal ini mengatur mengenai suatu perjanjian dengan ancaman hukuman, yaitu apabila dalam perjanjian itu para pihak memperjanjikan bahwa salah satu pihak yang lalai memenuhi perjanjian (wanprestasi), ia harus membayar sejumlah uang, yang dalam istilah seharihari disebut denda. Maka, pembayaran denda yang berupa uang tersebut harus dibayar sebesar nilai yang diperjanjikan, tidak boleh lebih atau kurang. ${ }^{26}$

Pasal 1250 KUHPerdata berbunyi sebagai berikut:

"Dalam perikatan yang hanya berhubungan dengan pembayaran sejumlah uang, penggantian biaya, kerugian dan bunga yang timbul karena keterlambatan pelaksanaannya, hanya terdiri atas bunga yang ditentukan oleh undangundang tanpa mengurangi berlakunya peraturan undang-undang khusus.

Penggantian biaya, kerugian dan bunga itu wajib dibayar, tanpa perlu dibuktikan adanya suatu kerugian oleh kreditur.

Penggantian biaya,. kerugian dan bunga itu baru wajib dibayar sejak

\footnotetext{
${ }^{26} I b i d .$, h. 70.
} 
diminta di muka Pengadilan, kecuali bila undang-undang menetapkan bahwa hal itu berlaku demi hukum."

Maksud pasal ini adalah bahwa setiap tagihan yang berupa uang, yang pembayarannya terlambat dilakukan oleh salah satu pihak, maka tuntutan ganti kerugian tidak boleh melebihi ketentuan bunga moratorium (bunga menurut undang-undang), yaitu sebesar 6\% (enam persen) per tahun, kecuali kalau ada undang-undang lain yang memberikan kemungkinan yang berbeda. ${ }^{27}$

Penghitungan besarnya ganti kerugian tersebut terhitung bukan pada saat lalainya seseorang, melainkan mulai dihitung sejak tuntutan tersebut diajukan ke pengadilan. Kecuali jika dalam keadaan tertentu undang-undang memberikan kemungkinan bahwa penghitungan bunga tersebut berlaku demi hukum (mulai saat terjadinya wanprestasi). ${ }^{28}$

Pasal 1251 KUHPerdata berbunyi sebagai berikut: "Bunga uang pokok yang dapat ditagih dapat pula menghasilkan bunga, baik karena suatu permohonan di muka Pengadilan, maupun karena suatu persetujuan yang khusus, asal saja permintaan atau persetujuan tersebut adalah mengenai bunga yang harus dibayar untuk satu tahun.”
Bunga sebesar $6 \%$ (enam persen) sebagaimana diatur pada Pasal 1250 KUHPerdata masih dapat pula berbunga, yaitu jika bunga moratorium itu pun masih terlambat dibayar oleh pihak yang melakukan wanprestasi, hanya bunga yang berbunga tersebut dimungkinkan bagi bunga yang harus dibayar untuk satu tahun, agar pembayaran bunga atas bunga tersebut dapat dipenuhi, maka dapat dilakukan dengan dua cara, yaitu dengan: ${ }^{29}$

1. Meminta di depan persidangan; atau

2. Memperjanjikannya.

Bunga-bunga yang disebutkan satu persatu pada pasal ini, berlaku terhitung mulai terjadinya penuntutan atau sejak dibuatnya perjanjian.

Pilihan tersebut dapat disertai ganti kerugian (biaya, rugi, dan bunga) kalau ada alasan untuk itu, artinya pihak yang menuntut ini tidak harus menuntut ganti kerugian, walaupun hal itu dimungkinkan berdasarkan pasal ini.

Berdasarkan pasal inilah sehingga banyak sarjana menguraikan pilihan tuntutan para pihak yang dirugikan tersebut menjadi empat kemungkinan tuntutan, yaitu: ${ }^{30}$

1. Pemenuhan perjanjian;

2. Pemenuhan perjanjian disertai ganti kerugian;
${ }^{27} I$ Ibid., h. 71.
${ }^{28}$ Ibid., h. 71.
${ }^{29}$ Ibid., h. 72.
${ }^{30}$ Ibid., h. 74. 
3. Pembatalan perjanjian;

\section{Analisis Pertimbangan Hukum}

\section{Majelis Hakim pada Putusan Nomor} 40/Pdt.G/2012/PN. Mdn.

Ruang lingkup Dilihat dari sengketa yang telah diuraikan sebelumnya, gugatan perdata dari penggugat sebagai pembeli ini timbul karena merasa dirugikan atas perjanjian lisan yang dibuat dengan penjual pada tanggal 23 September 2011. Menurut penggugat, tergugat (penjual) telah tidak melaksanakan perjanjian sesuai dengan apa yang mereka perjanjikan sebelumnya. Dalam kesepakatan awal, ditentukan bahwa penjual harus menyerahkan 12 (dua belas) unit mobil mircobus kepada pembeli pada tanggal 15 November 2011. Penggugat telah membayar uang muka sebesar $\mathrm{Rp}$ 60.000.000,- (enam puluh juta rupiah) yang merupakan bagian dari kesepakatan total 12 (dua belas) unit microbus seharga Rp 2.904.000.000,- (dua miliar sembilan ratus empat juta rupiah). Namun, dikarenakan perusahaan leasing menolak permohonan pengajuan leasing yang diajukan oleh tergugat, maka muncullah permasalahan antara tergugat dengan penggugat.

Menurut ketentuan Pasal 1865 KUHPerdata yang berbunyi: "Barang siapa yang mengaku mempunyai suatu hak atau menyebut suatu peristiwa untuk meneguhkan haknya atau membantah hak orang lain, harus membuktikan adanya hak atau peristiwa itu". Hak atau peristiwa yang harus dibuktikan di persidangan, harus dimuat di dalam fundamentum petendi sebagai dasar tuntutan, yang memberikan gambaran tentang kejadian materiil yang merupakan dasar tuntutan itu. Oleh karena itu, dalam sengketa ini masing-masing pihak dalam persidangan harus dapat membuktikan adanya suatu kejadian yang menjadi dasar tuntutan terhadap pihak lain. Pihak penggugat telah mengajukan 9 (sembilan) surat bukti dan 2 (dua) orang saksi, sedangkan tergugat mengajukan 24 (dua puluh empat) surat bukti dan 2 (dua) orang saksi. ${ }^{31}$

Berikut ini ialah tabel yang berisi tentang materi pertimbangan majelis hakim yang terdapat di dalam Putusan Nomor 40/Pdt.G/2012/PN. Mdn. disertai dengan analisisnya:
${ }^{31}$ Teguh Samudera, Hukum Pembuktian dalam Acara Perdata, Alumni, Bandung, 1992, h. 98. 


\begin{tabular}{|c|c|c|c|}
\hline No & Para Pihak & Pertimbangan Hakim & Analisis Pertimbangan Hakim \\
\hline 1 & $\begin{array}{l}\text { Penggugat: } \\
\text { CV Berlian } \\
\text { Trans }\end{array}$ & $\begin{array}{l}\text { Bahwa gugatan provisi } \\
\text { penggugat dalam gugatan } \\
\text { provisinya menurut penilaian } \\
\text { Majelis nilai pokok dari } \\
\text { permasalahan dalam gugatan } \\
\text { yang diajukan oleh } \\
\text { penggugat tidak seimbang } \\
\text { dengan harga tanah yang } \\
\text { dimohonkan untuk } \\
\text { diletakkan sita jaminan } \\
\text { dengan demikian gugatan } \\
\text { provisi penggugat tersebut } \\
\text { haruslah ditolak }\end{array}$ & $\begin{array}{l}\text { Hal ini memang sesuai, karena } \\
\text { jika dilihat dari harta yang } \\
\text { dimohonkan oleh penggugat } \\
\text { untuk diletakkan sita jaminan, } \\
\text { nilainya jauh melebihi nilai } \\
\text { gugatan dari penggugat, dan } \\
\text { juga putusan yang telah } \\
\text { diambil oleh majelis hakim. }{ }^{32}\end{array}$ \\
\hline 2 & $\begin{array}{l}\text { Tergugat: } \\
\text { PT } \\
\text { Isuindomas } \\
\text { Putra }\end{array}$ & $\begin{array}{l}\text { Bahwa berdasarkan surat } \\
\text { bukti P-2, P-3, P-5 dan surat } \\
\text { bukti P-7, P-9 penggugat } \\
\text { tidak dapat menunjukkan } \\
\text { aslinya di sidang berdasarkan } \\
\text { Putusan Mahkamah Agung } \\
\text { RI No. 701K/Sip/1974 } \\
\text { tanggal 14-04-1976 foto } \\
\text { copy yang dinyatakan tidak } \\
\text { sesuai dengan aslinya maka } \\
\text { surat-surat bukti tersebut } \\
\text { haruslah dikesampingkan }\end{array}$ & $\begin{array}{l}\text { Berdasarkan Pasal } 1888 \\
\text { KUHPerdata jo Yurisprudensi } \\
\text { Putusan Mahkamah Agung } \\
\text { Nomor } 701 \text { K/Sip/1974 } \\
\text { tanggal } 14 \text { April } 1976 \text { yang } \\
\text { menentukan bahwa, "kekuatan } \\
\text { pembuktian suatu bukti tulisan } \\
\text { adalah pada akta aslinya. } \\
\text { Apabila akta yang asli itu ada, } \\
\text { maka salinan-salinan serta } \\
\text { kutipan hanyalah dapat } \\
\text { dipercaya sepanjang salinan- } \\
\text { salinan itu sesuai dengan } \\
\text { aslinya, yang mana senantiasa } \\
\text { dapat diperintahkan untuk } \\
\text { ditunjukkan". Oleh karena itu } \\
\text { pertimbangan majelis hakim }\end{array}$ \\
\hline
\end{tabular}

${ }^{32}$ Soeroso, Hukum Acara Perdata Lengkap dan Praktis HIR, RBG, dan Yurisprudensi, Sinar Grafika, Jakarta, 2011, h. 93. 


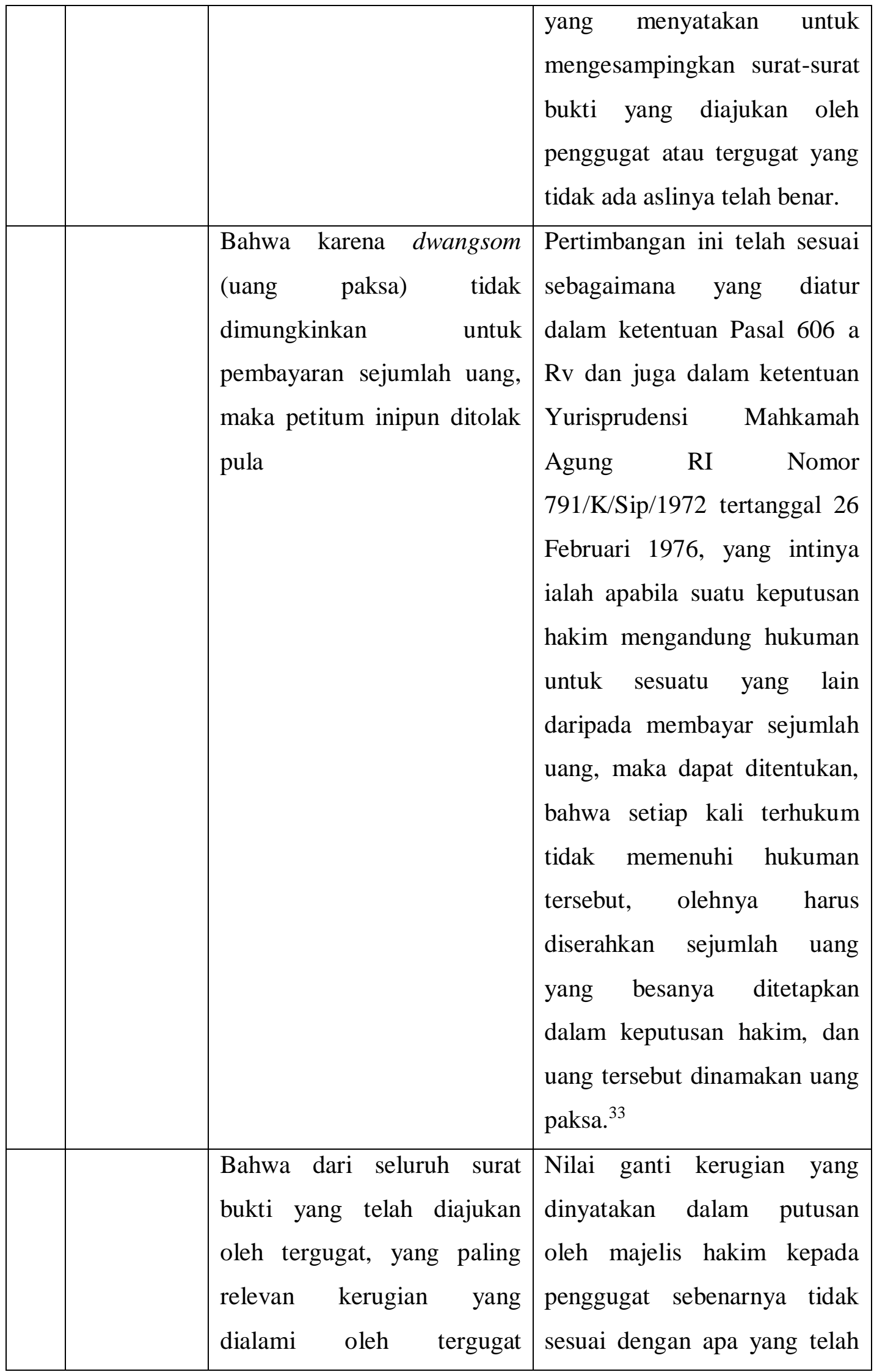

${ }^{33}$ Setiawan, Aneka Masalah Hukum dan Hukum Acara Perdata, Alumni, Bandung, 1992, h. 112. 


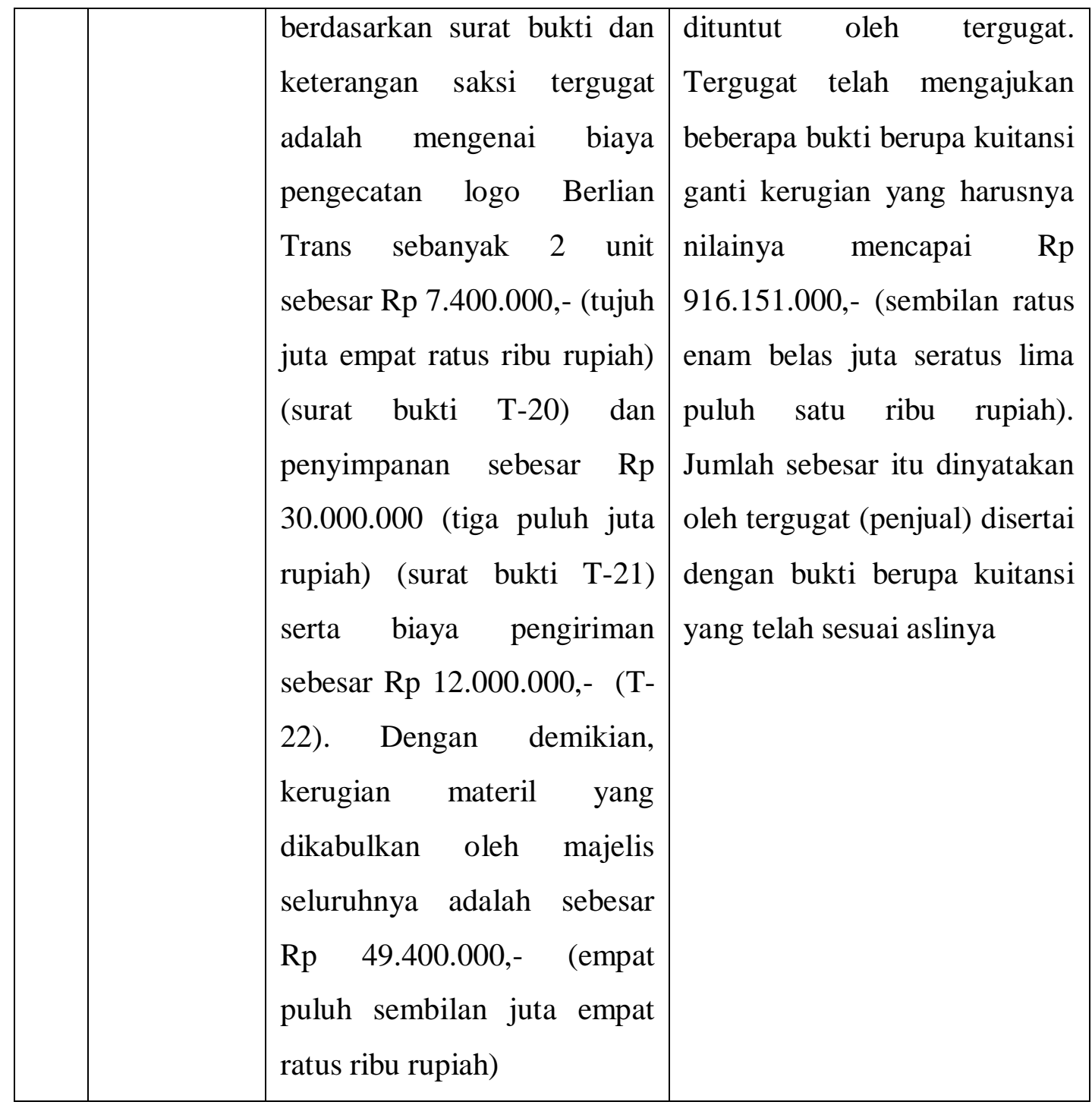

\section{E. Kesimpulan dan Saran}

\section{Kesimpulan}

a. Pentingnya Tercapainya suatu kesepakatan dalam perjanjian jual beli yang tidak tertulis itu saat para pihak yang bertemu itu sepakat untuk melakukan jual beli. Jual beli dianggap telah terjadi antara penjual dan pembeli, pada saat orang-orang itu mencapai kesepakatan tentang suatu barang beserta harganya, meskipun barang itu belum diserahkan dan harganya belum dibayar. Hal ini memperlihatkan apabila antara para pihak sudah menyetujui perjanjian mengenai suatu harga dan barang tertentu, maka di antara mereka telah terikat oleh perjanjian jual beli itu dan tidak boleh mengganggap perjanjian itu belum terjadi karena barang yang belum diserahkan. Sehingga apabila seseorang menyangkal bahwa belum terjadi perjanjian jual beli karena barang belum diserahkan, maka ia dapat dikatakan telah ingkar janji (wanprestasi). 
b. Akibat hukum yang timbul apabila para pihak melakukan wanprestasi dalam perjanjian jual beli yang tidak tertulis (lisan) yaitu muncul suatu hak bagi salah satu pihak yang dirugikan tersebut untuk menuntut empat hal sebagai berikut:

1) Pemenuhan perjanjian lisan;

2) Pemenuhan perjanjian lisan disertai ganti kerugian;

3) Pembatalan perjanjian lisan;

4) Pembatalan perjanjian lisan disertai ganti kerugian.

c. Pertimbangan hukum majelis hakim dalam sengketa perjanjian jual beli mobil microbus pada putusan nomor 40/Pdt.G/2012/PN. Mdn. secara keseluruhan sudah sesuai dengan aturan hukum yang berlaku, namun terdapat satu hal mengenai jumlah kerugian yang diwajibkan bagi penggugat untuk diganti kepada tergugat dari pertimbangan hakim tidak dijelaskan mengapa hanya dikabulkan beberapa dari tuntutan ganti kerugian materiil dari sekian banyak bukti yang diajukan tergugat dan telah sesuai dengan aslinya. Majelis hakim hanya mengabulkan sebesar Rp 49.400.000,- (empat puluh sembilan juta empat ratus ribu rupiah) dari total Rp 916.151.000,- (sembilan ratus enam belas juta seratus lima puluh satu ribu rupiah) yang dituntut. Dalam sengketa jual beli tersebut penggugat selaku pembeli (CV Berlian Trans) dan tergugat selaku penjual (PT Isuindomas Putra) sama-sama telah dinyatakan telah melakukan tindakan wanprestasi atas perjanjian jual beli yang telah mereka sepakati, sehingga masing-masing pihak tersebut mendapat hukuman, di mana tergugat diwajibkan mengembalikan uang muka sebagai tanda jadi sebesar Rp 60.000.000,- (enam puluh juta rupiah) kepada penggugat, sedangkan penggugat diharuskan membayar ganti kerugian sebesar Rp 49.400.000,(empat puluh sembilan juta empat ratus ribu rupiah) kepada tergugat. 


\section{F. Daftar Pustaka}

\section{Buku}

Adiwimarta, I.S. 1996. Pengantar Studi Hukum Perdata. Jakarta: PT RajaGrafindo Persada. Ali, Zainuddin. 2009. Metode Peneltian Hukum. Jakarta: Sinar Grafika.

Artha, Ratna Windasari. 2014. Hukum Perjanjian. Yogyakarta: Graha Ilmu.

Ashshofa, Burhan. 2007. Metode Penelitian Hukum. Jakarta: Rineka Cipta.

Badrulzaman, Mariam Darus. 1993. Kitab Undang-Undang Hukum Perdata Buku III tentang Hukum Perikatan dengan Penjelasan. Bandung: Alumni.

Badrulzaman, Mariam Darus. 2001. Kompilasi Hukum Perikatan. Bandung: Citra Aditya Bakti.

Basrah. 1981. Buku Ke-III KUH. Perdata tentang Perikatan Jual Beli dan Pembahasan Kasus. Medan: Fakultas Hukum USU.

Bruggink. 2015. Refleksi Tentang Hukum Pengertian-Pengertian Dasar dalam Teori Hukum. Bandung: PT Citra Aditya Bakti.

Dirdjosisworo, Soedjono. 2002. Misteri Dibalik Kontrak Bermasalah. Bandung: Mandar Maju.

Fuady, Munir. 2001. Hukum Kontrak (Dari Sudut Pandang Hukum Bisnis). Bandung: Citra Aditya Bakti.

Haposan, Rudy Siahaan. 2017. Hukum Perikatan Indonesia. Malang: Intelegensia Media.

H.S., Salim. 2002. Pengantar Hukum Perdata Tertulis (BW). Jakarta: Sinar Grafika.

H.S., Salim. 2011. Hukum Kontrak Teori dan Teknik Penyusunan Kontrak. Jakarta: Sinar Grafika.

Kamello, Tan. 2004. Hukum Jaminan Fidusia. Bandung: Almuni.

Kansil, C.S.T. 2004. Modul Hukum Perdata Termasuk Asas-asas Hukum Perdata. Jakarta: PT Pradnya Paramita.

Karya Ilmiah Dosen-Dosen Jurusan Perdata. 1980. Pelangi Perdata. Medan: Fakultas Hukum Universitas Sumatera Utara.

Kelsen, Hans. 2012. Pengantar Teori Hukum. Bandung: Nusa Media.

Komariah. 2010. Hukum Perdata. Malang: UMM Press.

Mulyadi, Lilik. 2005. Hukum Acara Perdata Menurut Teori dan Praktek Peradilan Indonesia, Jakarta: Djambatan. Cet ke-3.

Miru, Ahmad dan Pati, Saka. 2008. Hukum Perikatan Penjelasan Makna Pasal 1233 Sampai 1456 BW. Jakarta: PT Rajagrafindo Persada. 
Muhammad, Abdulkadir. 2000. Hukum Perdata Indonesia. Bandung: PT Citra Aditya Bakti.

— . 2003. Perikatan Pada Umumnya. Jakarta: PT Rajagrafindo Persada.

_ 2003. Perikatan yang Lahir dari Perjanjian. Jakarta: PT Rajagrafindo Persada.

— . 2003. Hapusnya Perikatan. Jakarta: PT Rajagrafindo Persada.

Prakoso, Djoko. 1987. Dasar Persetujuan Tertentu di Indonesia. Jakarta: PT Rina Aksara.

Satrio, J. 1995. Hukum Perikatan (Perikatan yang Lahir dari Perjanjian) Buku I. Bandung: PT Citra Aditya Bakti.

— 1995. Hukum Perikatan (Perikatan yang Lahir dari Perjanjian) Buku II. Bandung: PT. Citra Aditya Bakti.

- 1999. Hukum Perikatan, Perikatan pada Umumnya. Bandung: Alumni.

Setiawan. 1992. Aneka Masalah Hukum dan Hukum Acara Perdata. Bandung: Alumni.

Soekanto, Soerjono. 1986. Pengantar Penelitian Hukum. Jakarta: UI-Press.

Soeroso, R. 2010. Yurisprudensi Hukum Acara Perdata. Jakarta: Sinar Grafika.

— 2011. Hukum Acara Perdata Lengkap dan Praktis HIR, RBG, Dan Yurisprudensi. Jakarta: Sinar Grafika.

Subekti, 1995. Aneka Perjanjian. Bandung: Citra Aditya Bakti.

- 1990. Hukum Perjanjian, Jakarta: PT Intermasa.

— . 2003. Pokok-Pokok Hukum Perdata. Jakarta: PT Intermasa.

Suharnoko. 2015. Hukum Perjanjian Teori Dan Analisa Kasus. Jakarta: Kencana.

Syahrani, Riduan. 1992. Seluk Beluk dan Asas-asas Hukum Perdata. Bandung: Alumni.

Widjaja, Gunawan. 2006. Seri Hukum Bisnis Memahami Prinsip Keterbukaan (Aanvullend Recht) dalam Hukum Perdata. Jakarta: PT Rajagrafindo Persada.

Widjaja, Gunawan dan Muljadi, Kartini. 2003. Seri Hukum Perikatan Jual Beli. Jakarta: PT Rajagrafindo Persada.

Wirjono, Prodjodikoro. 1981. Hukum Perdata tentang Persetujuan-Persetujuan Tertentu. Bandung: Sumur Bandung.

Wirjono, Prodjodikoro. Hukum Perdata tentang Hak-hak Atas Benda. Jakarta: PT Pembimbing Masa.

Yahman. 2015. Karakteristik Wanperstasi dan Tindak Pidana Penipuan. Jakarta: Kencana.

Yudha, Agus Hernoko. 2010. Hukum Perjanjian Asas Prporsionalitas dalam Kontrak Komersial. Jakarta: Kencana.

Zainal, Idris, 1983. Ketentuan Jual Beli Menurut Hukum Perdata. Medan: Fakultas Hukum USU. 


\section{Jurnal}

Ayu, Aditya Hakiki, dkk. Perlindungan Hukum bagi Pembeli dalam Sengketa Jual Beli Online. Justitia Jurnal Hukum. Volume 1. Nomor 1. April 2017.

Elizabeth, Riry Hutabarat. Wanprestasi dalam Perjanjian Jual Beli Tenaga Listrik. Jurnal Lex Jurnalica. Volume 12. Nomor 1. April 2015.

Handriani, Aan. Keabsahan Perjanjian Jual Beli Secara Tidak Tertulis Berdasarkan Hukum Perdata. Rechtsregel Jurnal Ilmu Hukum. Volume 1. Nomor 2. Desember 2018.

Harefa, Billy Dicko Stepanus. Kekuatan Hukum Perjanjian Lisan Apabila Terjadi Wanprestasi (Studi Putusan Pengadilan Negeri Yogyakarta Nomor 44/Pdt.G/2015/Pn.Yyk). Privat Law. Volome 4. Nomor 2. Juli-Desember 2016.

Langi, Marvita. Akibat Hukum Terjadinya Wanprestasi dalam Perjanjian Jual Beli. Lex Privatum. Volume 4. Nomor 3. Maret 2016.

Noviansyah, Kurnia Oetama. dkk. Pelaksanaan Perjanjian Kerja Secara Lisan antara Klub dengan Pemain pada Klub Futsal Atlas Muda Semarang. Diponegoro Law Journal. Volume 5. Nomor 4. 2016.

Perdana, Afrilian. 2014. Penyelesaian Wanprestasi dalam Perjanjian Jual Beli Melalui Media Elektronik. Jurnal Ilmu Hukum Pascasarjana Universitas Syiah Kuala. Volume 2. No. 1. Februari 2014.

Ramadhan, Akbar, dkk. Kekuatan Hukum Garansi Secara Lisan dalam Perjanjian Jual Beli Komputer Rakitan. Pactum Law Journal. Volume 1. Nomor 04. 2018.

Sitompul, Fajar Sahat Ridoli. dan Ariani, I Gst Ayu Agung. Kekuatan Mengikat Perjanjian yang Dibuat Secara Lisan. Kertha Semaya. Volume 2. Nomor 5. Juli 2014. 